\title{
Bloodstream bacterial infection among outpatient children with acute febrile illness in north-eastern Tanzania
}

\author{
Coline Mahende ${ }^{1,2^{*}}$, Billy Ngasala², John Lusingu ${ }^{1,3}$, Allvan Butichi ${ }^{1}$, Paminus Lushino ${ }^{1}$, Martha Lemnge ${ }^{1}$,
} Bruno Mmbando ${ }^{1}$ and Zul Premji ${ }^{2}$

\begin{abstract}
Background: Fever is a common clinical symptom in children attending hospital outpatient clinics in rural Tanzania, yet there is still a paucity of data on the burden of bloodstream bacterial infection among these patients.

Methods: The present study was conducted at Korogwe District Hospital in north-eastern Tanzania. Patients aged between 2 and 59 months with a history of fever or measured axillary temperature $\geq 37.5^{\circ} \mathrm{C}$ attending the outpatient clinic were screened for enrolment into the study. Blood culturing was performed using the BACTEC $9050^{\circledR}$ system. A biochemical analytical profile index and serological tests were used for identification and confirmation of bacterial isolates. In-vitro antimicrobial susceptibility testing was performed using the Kirby-Bauer disc diffusion method. The identification of Plasmodium falciparum malaria was performed by microscopy with Giemsa stained blood films.

Results: A total of 808 blood cultures were collected between January and October 2013. Bacterial growth was observed in 62/808 (7.7\%) of the cultured samples. Pathogenic bacteria were identified in 26/808 (3.2\%) cultures and the remaining 36/62 (58.1\%) were classified as contaminants. Salmonella typhi was the predominant bacterial isolate detected in 17/26 (65.4\%) patients of which 16/17 (94.1\%) were from patients above 12 months of age. Streptococcus pneumoniae was the second leading bacterial isolate detected in 4/26 (15.4\%) patients. A high proportion of $S$. typhi $11 / 17(64.7 \%)$ was isolated during the rainy season. S. typhi isolates were susceptible to ciprofloxacin $(n=17 / 17$, $100 \%)$ and ceftriaxone $(n=13 / 17,76.5 \%)$ but resistant to chloramphenicol $(n=15 / 17,88.2 \%)$. P. falciparum malaria was identified in 69/808 (8.5\%) patients, none of whom had bacterial infection.

Conclusion: Bloodstream bacterial infection was not found to be a common cause of fever in outpatient children; and S. typhi was the predominant isolate. This study highlights the need for rational use of antimicrobial prescription in febrile paediatric outpatients presenting at healthcare facilities in rural Tanzania.
\end{abstract}

Keywords: Bacterial infection, Salmonella typhi, Malaria, Children, Antimicrobial sensitivity, Korogwe, Tanzania

\section{Background}

Bacterial bloodstream infections are known common causes of febrile illnesses especially among children living in resource poor areas of sub-Saharan Africa [1]. The epidemiology of bacterial infections varies across the world depending on geographical environment,

\footnotetext{
*Correspondence: cbdmahende@yahoo.co.uk

${ }^{1}$ Korogwe Research Laboratory, Tanga Centre, National Institute

for Medical Research, P. O. Box 5004, Tanga, Tanzania

Full list of author information is available at the end of the article
}

social-economical status and the underlying illnesses such as malaria and human immunodeficiency virus (HIV) [2-4]. Invasive bacterial infections among hospitalized children have been extensively studied yet limited data exist on the disease burden among outpatient children living in rural settings of Tanzania [5].

Bacterial infections among inpatient children in many parts of sub-Saharan Africa have been documented to be caused mainly by non-typhoidal Salmonella, Streptococcus pneumoniae, Haemophilus influenzae and Escherichia coli $[1,6,7]$. Current data indicate differing 
and changing pattern of bacterial infections in areas with declining malaria and HIV transmissions [3, 8-11]. Therefore, understanding the local epidemiology of pathogens is essential for early disease interventions.

The general clinical symptoms observed in patients with invasive bacterial infections include fever, headache, abdominal pain, vomiting, diarrhoea and malaise [12]. Like other febrile illnesses, these signs and symptoms are non-specific and may overlap with other febrile infections making diagnosis in children difficult and challenging in the absence of appropriate laboratory confirmation $[13,14]$. The majority of healthcare facilities with the exception of a few research laboratories in rural African countries, lack adequate microbiologic blood culture facilities; which is the universally preferred and effective standard method for detection of bacterial pathogens [15]. As a result, clinicians incorrectly diagnose and treat patients based on clinical symptoms rather than laboratory evidence. Consequently, patients are often given the wrong diagnosis, which leads to inappropriate treatment, poor prognosis and promotion of antimicrobial drug resistance $[16,17]$.

Empirical fever treatment with antimicrobials such as amoxicillin and chloramphenicol obtained over the counter without prescription is common in Tanzania, and this accentuates the problem of antimicrobial resistance [18]. Multiple drug resistance among Gram negative bacterial isolates has been spreading and increasing globally over the years [19-21]. The antimicrobial susceptibility patterns vary with geographical location, therefore, periodic surveillance of local patterns is crucial in monitoring this problem as well as for correct prescriptions and future targets for treatments.

A majority of studies have documented bacterial infections among hospitalised patients who are usually severely ill and already exposed to antimicrobial drugs before seeking professional medical care [22]. In Tanzania, data on the burden of bacterial infection among children attending outpatient clinics in rural hospitals is lacking. With the current observations on changing patterns of bacterial infections, local prevalence and antimicrobial resistance profile need to be characterised for timely interventions. The objective of the study was to identify bloodstream bacterial infections causing fever in young children attending outpatient clinic at Korogwe District Hospital in north-eastern Tanzania. The study characterised the in vitro antimicrobial susceptibility pattern of bacterial isolates and provided an outline on the clinical characteristics of patients with bacterial infections.

\section{Methods}

\section{Study area}

The study was conducted at Korogwe District Hospital (KDH) in Korogwe District north-eastern Tanzania (Figure 1). Approximately 73,275 children under the age of

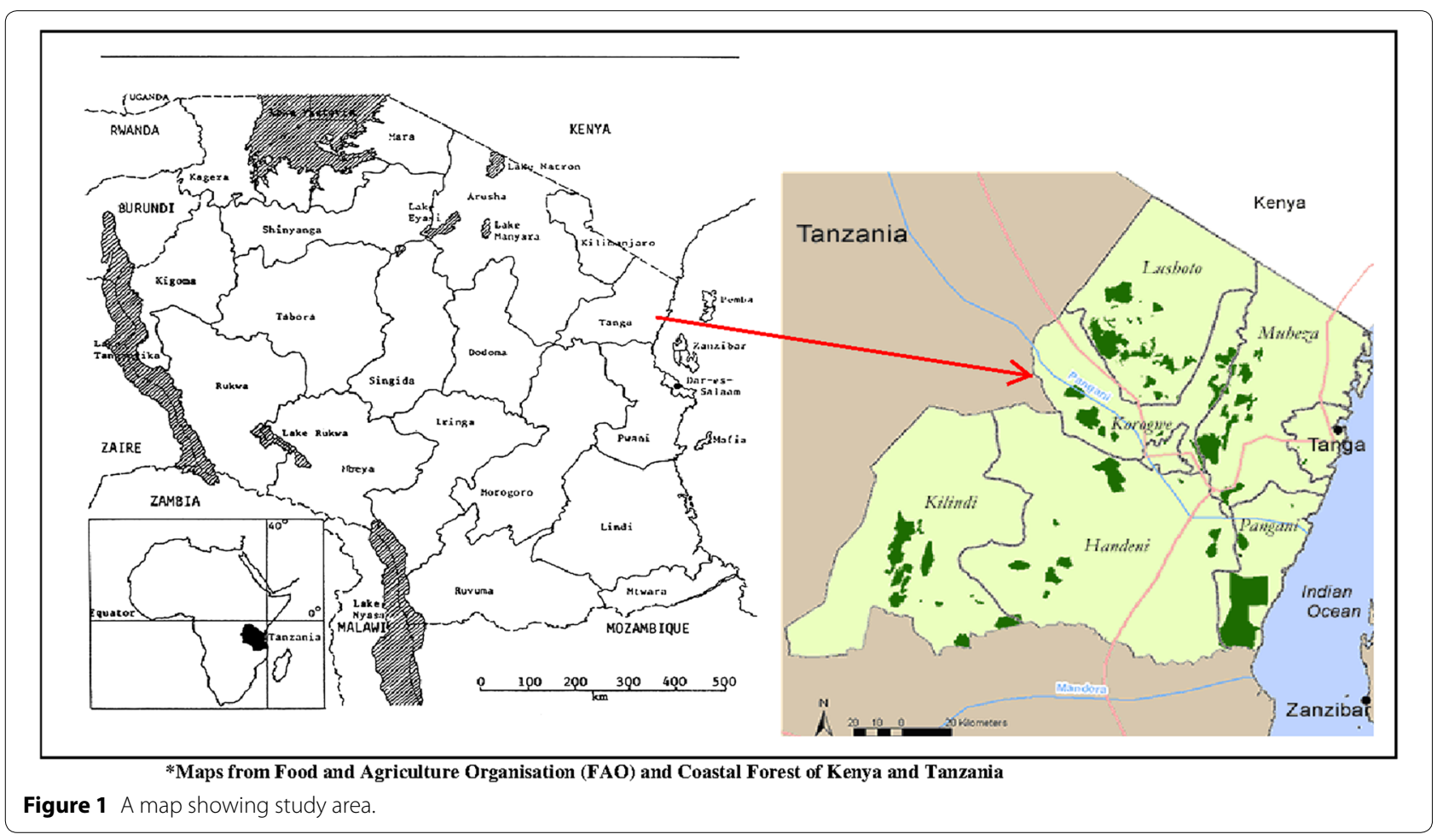


5 years live in Korogwe District [23]. The District experiences temperatures between 18 and $20^{\circ} \mathrm{C}$ during the rainy season and $26-30^{\circ} \mathrm{C}$ during the dry season. The annual rainfall ranges from 700 to $1,000 \mathrm{~mm}$ with long rainy seasons extending from March to May and short rains in September and October. The majority of inhabitants $(80 \%)$ reside in rural settings, practicing subsistence farming and informal trade. The hospital receives around 6,000 (2012 estimates) outpatient visits from under fives annually. The Korogwe District is an area with declining malaria transmission with a prevalence of around 13\% according to surveys conducted from 2003 to 2008 [24]. Pneumococcal and rotavirus vaccines were introduced in Tanzania as part of the Expanded Program on Immunization (EPI) in January 2013. The administrative coverage for other vaccines in the EPI has been above $90 \%$ (Korogwe Primary Health Care report, District Medical Officer, personal communication). These vaccines include; Bacille Calmette-Guérin, pentavalent vaccine (diphtheria-tetanus-pertussis, hepatitis B and haemophilus influenza type $B$ ), poliovirus and measles vaccines.

\section{Study participants}

The study was conducted from January 2013 to October 2013 where febrile children presenting at KDH outpatient clinic were assessed for enrolment. The inclusion criteria were: children aged between 2 and 59 months presenting at $\mathrm{KDH}$ with a history of fever in the last $48 \mathrm{~h}$ or measured axillary temperature of $\geq 37.5^{\circ} \mathrm{C}$ at presentation. Exclusion criteria included previous consultation for the presenting complaints, intake of antimalarial and/ or antibiotic drugs within the last 7 days, planned admissions (e.g. elective surgery) and trauma/injury.

\section{Ethics statement}

The study was granted ethical clearance with reference number NIMR/HQ/R.8a/Vol.1X/1373 from the Tanzanian Medical Research Coordinating Committee. Parent/legally accepted guardian of every child enrolled in the study provided a written informed consent by either signature or thumb print for the illiterate parent/legally accepted guardian.

\section{Study procedures}

A detailed medical history and a thorough clinical examination were performed on each patient and information was entered into a standardised case record form. This included demographic information, clinical history, physical examination data, vital signs (axillary temperature and respiratory rate) and body weight. Clinical diagnosis was made based on presenting signs and symptoms according to Integrated Management of Childhood Illness (IMCI) guidelines [25] so that patients could be managed appropriately according to the national standard practice $[26,27]$ while waiting for blood culture results.

\section{Blood sampling and laboratory investigations}

A maximum of $5 \mathrm{ml}$ of venous blood was collected for laboratory investigations using aseptic techniques. Blood was drawn after disinfecting the venipuncture site with $70 \%$ isopropyl alcohol and iodine. A blood volume of between 1 and $3 \mathrm{ml}$ was inoculated into commercial BD BACTEC PEDS PLUS culture bottles. A single aerobic culture bottle was used per patient. The inoculated blood culture bottles were immediately (that was within $2 \mathrm{~h}$ ) incubated at $35^{\circ} \mathrm{C}$ in the BACTEC $9050^{\circ}$ (Becton-Dickinson, Sparks, MD, USA) culture system for a maximum of 5 days unless flagged positive. Sheep-blood, MacConkey and chocolate agar plates with the use of routine microbiological techniques were used for sub-culturing positive samples according to standard methods. Analytical Profile Index (API) biochemical test kit (BioMérieux ${ }^{{ }^{\mathrm{Tm}}}$, France) was used to identify pathogens. Salmonella isolates were confirmed by serological tests using specific antisera (Becton-Dickinson, Sparks, MD, USA).

In-vitro antimicrobial susceptibility testing for pathogenic bacterial isolates was performed using the KirbyBauer disc diffusion method. The antimicrobial agents tested included; amoxicillin $(10 \mu \mathrm{g})$, cefoxitin $(30 \mu \mathrm{g})$, ceftriaxone $(30 \mu \mathrm{g})$, chloramphenicol $(30 \mu \mathrm{g})$, ciprofloxacin $(5 \mu \mathrm{g})$, clarithromycin $(2 \mu \mathrm{g})$, co-trimoxazole $(1.25 \mu \mathrm{g})$, gentamicin $(10 \mu \mathrm{g})$, penicillin $(1 \mu \mathrm{g})$ and tetracycline $(30 \mu \mathrm{g})$. Clinical and Laboratory Standards Institute (CLSI) criteria were used in the interpretation of zone sizes [28].

The identification of malaria infection was performed by microscopy. Thick and thin blood smears were prepared from venous blood collected in the ethylene diamine tetra acetic acid (EDTA) tubes. Blood slides were stained with a $5 \%$ Giemsa solution for $30 \mathrm{~min}$ and examined for asexual Plasmodium falciparum parasites. The parasite densities were calculated against 200 (500 if parasite count was $<10$ ) leucocytes multiplied by the patient's leucocyte count and expressed as parasites $/ \mu \mathrm{l}$. At least 100 high power microscopic fields of the thin film were examined to exclude the diagnosis of malaria. The slides were independently double-read by experienced microscopists and in case of discrepancy, a third reading was performed. The complete blood count was analysed using the automated MS4s haematological analyser (Melet Schloesing Diamond Diagnostics, USA).

\section{Quality control and assessment}

Laboratory investigations were carried out at Korogwe Research Laboratory of the Tanzanian National Institute for Medical Research. Quality control was performed for 
all laboratory methods according to standard guidelines [29]. During the study, the laboratory participated in the bacteriology external quality assessment programme with the National Institute for Communicable Diseases (NICD) registration number 107.

\section{Case definitions}

Fever was defined as history of abnormally high body temperature reported by the parent/guardian or measured axillary temperature $\geq 37.5^{\circ} \mathrm{C}$ on presentation. Bloodstream bacterial infection (bacteraemia) was defined as fever with isolation of pathogenic bacteria from a positive blood culture. A contaminant was defined as non-pathogenic bacteria (mostly from skin) such as coagulase-negative Staphylococcus species, Corynebacterium species, alpha- or gamma-hemolytic streptococci, Micrococcus species, Bacillus species and Propionibacterium species. However, a definitive diagnosis of a contaminant was decided by a clinician based on the clinical presentation of the patient considering that these organisms could be the cause of an opportunistic infection. The monthly cut-off point for contamination rate during the study was $6 \%$. Malaria infection was defined as fever with the presence of asexual $P$. falciparum parasites in a blood smear confirmed by microscopy. Clinical diagnoses were defined according to the IMCI guidelines [25]. Anaemia was defined as haemoglobin concentration below $9.3 \mathrm{~g} / \mathrm{dL}$. The reference interval used was $4.5-17 \times 10^{3} / \mu \mathrm{L}$ for leucocyte count.

\section{Data management and statistical analysis}

Data management involved double entry and validation using Microsoft Access 2007. Data analysis was done by STATA version 11.2 (Stata Corp LP, College Station, TX, USA). Variables were summarized as frequencies and percentages, medians and inter-quartile ranges as appropriate. Categorical data were compared by the Chi-square test. The logistic regression (odds ratio and 95\% confidence interval) was used to determine association of clinical diagnosis at enrolment with the occurrence of bacteraemia. The $P$ value $<0.05$ was considered significant.

\section{Results}

During the study period of January 2013 to October 2013, a total of 1,380 patients were screened for enrolment. Five hundred and thirteen patients $(37.2 \%)$ did not meet the inclusion criteria; 51/513 (9.9\%) patients were not within the required age group, 153/513 (29.8\%) patients were afebrile, 219/513 (42.7\%) patients had used antimalaria/antimicrobial drug within 7 days prior to screening and $90 / 513$ (17.5\%) patients refused participation. The remaining $867 / 1,380(62.8 \%)$ patients were recruited of whom 808 had blood culture samples collected.

The median age of patients was 15.6 months (Interquartile range: $8.9-30.0)$. The sex ratio was $431 / 808$ (53.3\%) boys and 377/808 (46.7\%) girls. The demographic profile of patients is indicated in Table 1.

Bacterial growth was observed in 62/808 (7.7\%) of the cultured samples. Single pathogenic bacteria were isolated from 26/808 (3.2\%) cultures. The remaining 36/62 (58.1\%) were classified as contaminants. Coagulase-negative staphylococcus was the most frequently isolated contaminant with $21 / 36$ (58.3\%) of the bacterial isolates followed by micrococcus $9 / 36$ (25\%), Corynebacterium species $3 / 36$ (8.3\%), lactobacillus 1/36 (2.8\%), Sphingomonas paucimobilis $1 / 36$ (2.8\%) and Citrobacter braakii $1 / 36(2.8 \%)$. Blood cultures that flagged positive from the BACTEC $9050^{\circ}$ culture system with no bacteria growth accounted for 8/808 (0.9\%) of the positive cultures.

Gram negative bacteria were the leading pathogenic bacterial isolates compared to the Gram positive bacteria. Salmonella typhi was the most prevalent bacterial isolate identified in 17/26 (65.4\%) cultures followed by $S$. pneumoniae at $4 / 26(15.4 \%)$ and others as shown in Table 2. Pathogenic bacteria $(n=20 / 26,76.9 \%)$ were commonly isolated from patients below 36 months of age. The majority of S. typhi 16/17 (94.1\%) were isolated from patients above 12 months of age whilst nontyphoidal Salmonella $2 / 2(100 \%)$ were from patients below 12 months of age (Table 2). A high proportion of S. typhi, 11/17 (64.7\%), was isolated during the rainy season (March to May and September to October). Bloodstream bacterial infection was not associated with gender $\left(\chi^{2}=0.2, P=0.65\right)$.

Clinical diagnosis and laboratory findings at enrolment of patients with bacteraemia were compared with those without bacteraemia (Table 1). The proportion of bacteraemic patients with measured axillary temperature of $\geq 39^{\circ} \mathrm{C}$ was not of statistical significance $\left(\chi^{2}=2.85\right.$, $P=0.09)$ when compared to the non-bacteraemic group. Out of 159/808 (19.7\%) patients with clinical diagnosis of gastroenteritis, 8/159 (5\%) patients had positive blood cultures and among them, six were $S$. typhi isolates. One S. pneumoniae isolate was identified from a patient with a clinical diagnosis of pneumonia. P. falciparum malaria was identified in 69/808 (8.5\%) patients, none of whom had bacterial infection. Patients with the clinical diagnosis of non-specific febrile illness were at higher risk of having bacteraemia (OR $=7.6,95 \%$ CI 3.3-17.4), $P$ value $<0.01$ ). Eight $S$. typhi and two S. pneumoniae isolates were identified from these patients.

In-vitro antimicrobial susceptibility testing to selected antimicrobial agents was assessed for all pathogenic 
Table 1 Demographic characteristics and clinical diagnosis of patients with bacteraemia

\begin{tabular}{|c|c|c|c|}
\hline & Bacteraemia positive $(n=26)$ & Bacteraemia negative $(n=782)$ & $P$ value \\
\hline Girls & $11(42.3)$ & $366(46.8)$ & 0.65 \\
\hline \multicolumn{4}{|l|}{ Age } \\
\hline 2-35 months & $20(76.9)$ & $654(83.6)$ & \multirow[t]{3}{*}{0.40} \\
\hline 36-59 months & $6(23.1)$ & $128(16.4)$ & \\
\hline Axillary temperature $\left({ }^{\circ} \mathrm{C}\right)$, median (IQR) & $38.3(37.6-39.3)$ & $38(37.5-38.7)$ & \\
\hline Axillary temperature $\geq 39^{\circ} \mathrm{C}$ & $7(26.9)$ & $116(14.8)$ & 0.09 \\
\hline \multicolumn{4}{|l|}{ Symptoms } \\
\hline Cough & $5(19.2)$ & $360(46.0)$ & 0.01 \\
\hline Shortness of breath & $2(7.7)$ & $87(11.1)$ & 0.58 \\
\hline Diarrhoea & $6(23.1)$ & $155(19.8)$ & 0.68 \\
\hline \multicolumn{4}{|l|}{ Clinical diagnosis at enrolment } \\
\hline Malaria & $0(0)$ & $69(8.8)$ & 0.11 \\
\hline Gastroenteritis & $8(30.8)$ & $151(19.3)$ & 0.15 \\
\hline Upper respiratory tract infection & $3(11.5)$ & $309(39.5)$ & $<0.01$ \\
\hline Pneumonia & $2(7.7)$ & $114(14.6)$ & 0.33 \\
\hline Other infections $s^{\mathrm{a}}$ & $1(3.8)$ & $59(7.5)$ & 0.17 \\
\hline Multiple infections ${ }^{\mathrm{a}}$ & $3(11.5)$ & $140(17.9)$ & 0.40 \\
\hline Non-specific febrile illness & $12(46.2)$ & $80(10.2)$ & $<0.01$ \\
\hline \multicolumn{4}{|l|}{ Laboratory findings $(n=785$ ) } \\
\hline Anaemia & $6 / 26(23.1)$ & 203/759 (26.7) & 0.68 \\
\hline Leucocyte count $\left(10^{3} / \mu \mathrm{L}\right)$, median (IQR) & $10.4(7.5-16.3)$ & $11.5(8.6-15.7)$ & \\
\hline Leucocyte count $>17\left(10^{3} / \mu \mathrm{L}\right)$ & $6 / 26(23.1)$ & $157 / 759(20.7)$ & 0.77 \\
\hline
\end{tabular}

Data are $\mathrm{n}(\%)$, IQR inter-quartile range.

a Conjunctivitis, fungal infection, gingivitis, hookworm infection, otitis media, skin infection, urinary tract infection.

Table 2 Distribution of pathogenic bacterial isolates (\%) according to age groups

\begin{tabular}{|c|c|c|c|c|}
\hline & \multicolumn{4}{|c|}{ Age group } \\
\hline & $\begin{array}{l}2-11 \\
\text { months }\end{array}$ & $\begin{array}{l}12-35 \\
\text { months }\end{array}$ & $\begin{array}{l}36-59 \\
\text { months }\end{array}$ & $\begin{array}{l}\text { Total } \\
\text { n (\%) }\end{array}$ \\
\hline $\begin{array}{l}\text { Blood cultures } \\
\text { collected }\end{array}$ & 320 & 354 & 134 & 808 \\
\hline \multicolumn{5}{|c|}{ Gram positive bacteria } \\
\hline $\begin{array}{l}\text { Staphylococcus } \\
\text { aureus }\end{array}$ & $0(0)$ & $1(6.7)$ & $0(0)$ & $1(3.8)$ \\
\hline $\begin{array}{l}\text { Streptococcus } \\
\text { pneumoniae }\end{array}$ & $1(20)$ & $3(20)$ & $0(0)$ & $4(15.4)$ \\
\hline \multicolumn{5}{|c|}{ Gram negative bacteria } \\
\hline $\begin{array}{c}\text { Enterobacter } \\
\text { cloaccae }\end{array}$ & $0(0)$ & $1(6.7)$ & $0(0)$ & $1(3.8)$ \\
\hline Escherichia coli & $1(20)$ & $0(0)$ & $0(0)$ & $1(3.8)$ \\
\hline $\begin{array}{l}\text { Non-typhoidal } \\
\text { Salmonella }\end{array}$ & $2(40)$ & $0(0)$ & $0(0)$ & $2(7.7)$ \\
\hline Salmonella typhi & $1(20)$ & $10(66.7)$ & $6(100)$ & $17(65.4)$ \\
\hline $\begin{array}{l}\text { Total bacterial } \\
\text { isolates }\end{array}$ & 5 & 15 & 6 & 26 \\
\hline
\end{tabular}

bacterial isolates. S. typhi isolates were susceptible to ciprofloxacin 17/17(100\%) and resistant to chloramphenicol $15 / 17$ (88.2\%). A susceptibility rate of $100 \%$ was observed for S. pneumoniae isolates to chloramphenicol. All bacterial isolates were observed to have high rates of resistance to amoxicillin and co-trimoxazole (Table 3).

\section{Discussion}

In the current study, bloodstream bacterial infection was not found to be a common cause of fever in outpatient children from rural Tanzania. Three previous studies which investigated bacterial infection similar to the present study also showed a low prevalence of bacteraemia in the range of 1 and 5\% [5, 30, 31]. A recent published finding of D'Acremont et al., indicated evidence of a viral origin $(70 \%)$ to be more common than evidence of a bacterial or parasitic origin in outpatient febrile children from Tanzania [5]. When the distribution of pathogenic bacteria was characterized according to age group, patients below 36 months of age had a higher prevalence of bacterial infection. A significant number of studies on 
Table 3 In-vitro antimicrobial susceptibility pattern of bacterial isolates

\begin{tabular}{|c|c|c|c|}
\hline Antimicrobial agent & $\begin{array}{l}\text { Susceptible } \\
\mathrm{n}(\%)\end{array}$ & $\begin{array}{l}\text { Intermediate } \\
\text { n (\%) }\end{array}$ & $\begin{array}{l}\text { Resistant } \\
\mathrm{n}(\%)\end{array}$ \\
\hline \multicolumn{4}{|c|}{ Salmonella typhi $(\mathrm{n}=17)$} \\
\hline Amoxicillin & $2(11.8)$ & $0(0)$ & 15 (88.2) \\
\hline Ceftriaxone & $13(76.5)$ & $3(17.6)$ & $1(5.9)$ \\
\hline Chloramphenical & $2(11.8)$ & $0(0)$ & $15(88.2)$ \\
\hline Ciprofloxacin & $17(100)$ & $0(0)$ & $0(0)$ \\
\hline Gentamicin & $8(47.1)$ & $5(29.4)$ & $4(23.5)$ \\
\hline Co-trimoxazole & $1(5.9)$ & $2(11.8)$ & $14(82.4)$ \\
\hline \multicolumn{4}{|c|}{ Streptococcus pneumoniae $(n=4)$} \\
\hline Amoxicillin & $1(25)$ & $0(0)$ & $3(75)$ \\
\hline Cefoxitin & $2(50)$ & $1(25)$ & $1(25)$ \\
\hline Ceftriaxone & $3(75)$ & $1(25)$ & $0(0)$ \\
\hline Chloramphenicol & $4(100)$ & $0(0)$ & $0(0)$ \\
\hline Clarithromycin & $3(75)$ & $0(0)$ & $1(25)$ \\
\hline Co-trimoxazole & $0(0)$ & $0(0)$ & $4(100)$ \\
\hline Penicillin & $0(0)$ & $0(0)$ & $4(100)$ \\
\hline \multicolumn{4}{|c|}{ Other Enterobacteriaceae $(n=4)$} \\
\hline Amoxicillin & $2(50)$ & $0(0)$ & $2(50)$ \\
\hline Ceftriaxone & $4(100)$ & $0(0)$ & $0(0)$ \\
\hline Chloramphenicol & $3(75)$ & $0(0)$ & $1(25)$ \\
\hline Ciprofloxacin & $4(100)$ & $0(0)$ & $0(0)$ \\
\hline Gentamicin & $1(25)$ & $1(25)$ & $2(50)$ \\
\hline Co-trimoxazole & $2(50)$ & $0(0)$ & $2(50)$ \\
\hline \multicolumn{4}{|c|}{ Staphylococcus aureus $(\mathrm{n}=1)$} \\
\hline Cefoxitin & $0(0)$ & $0(0)$ & $1(100)$ \\
\hline Chloramphenicol & $1(100)$ & $0(0)$ & $0(0)$ \\
\hline Gentamicin & $1(100)$ & $0(0)$ & $0(0)$ \\
\hline Penicillin & $0(0)$ & $0(0)$ & $1(100)$ \\
\hline
\end{tabular}

bacteraemia in African children have reported higher prevalence of bacterial isolates from children below 36 months of age similar to what is reported in this paper $[20,32]$. Young children are usually susceptible to infections because of their immature immune system [33]. This study did not find any association between gender and bacterial infection in contrast to what was reported by Were and colleagues on the study among Kenyan children [13].

The Gram negative bacteria were the leading isolates with $S$. typhi being the most predominant. This indicates the occurrence of typhoid fever among young pre-school children in this particular community, which was otherwise thought to be uncommon within this age group [7]. Recent published work from sub-Saharan African countries with declining malaria transmissions has reported the predominance of S. typhi bacteria over other bacterial isolates (especially the non-typhoidal Salmonella) $[31,34,35]$. The current findings from the study which was conducted in an area with low prevalence of malaria infection are in keeping with previous findings [11, 36]. The observed change in the epidemiological pattern of bacterial infections may have been due to the scaling up of malaria interventions, better detection methods of malaria and the introduction of pneumococcal vaccination [37]. Continuous surveillance of bacterial infections is crucial for both current and future disease interventions.

Nearly two-thirds of S. typhi isolates were identified during the rainy season suggesting that the environmental risk factors are important to the occurrence of typhoid [38]. Similar associations have been found in Malawi and Sierra Leone where the frequency of Salmonella infections has been associated with the rainy season [39, 40]. Therefore, Tanzania and other low-income countries should take measures and work towards protecting water sources in rural areas for control against spreading of the bacteria. This can be attained through good sanitation to safe water and public health education on personal and food hygiene. Simultaneously, researchers and pharmaceutical companies should expedite development of vaccine against typhoid for immunization in children. Currently, typhoid vaccine is available for adult travelers from developed countries [41, 42].

In those patients who had the clinical diagnosis of nonspecific febrile illness at enrolment, the use of clinical symptoms and IMCI guidelines missed nearly half of the patients with culture-confirmed enteric fever. Apart from being febrile, these patients did not have other clinical symptoms or an elevated leucocyte count. Such patients would return at a future date with severe conditions requiring inpatient hospital stay. The availability of blood culture facility in the study has highlighted the importance of confirming the diagnosis of febrile illnesses caused by bacterial infections in children seeking hospital care. However, this is a difficult challenge to implement in hospital facilities in resource poor areas. These findings emphasize the need to develop highly sensitive and affordable point of care rapid diagnostic tests for use in resource limited areas to provide prompt detection of bacterial infections and timely initiation of effective antimicrobial therapy. This iterates the need of improving and having adequate microbiology laboratories at secondary healthcare facilities for local surveillance of bacteria pathogens as well as antimicrobial susceptibility patterns.

Chloramphenicol was not effective during the in vitro antimicrobial susceptibility testing of $S$. typhi isolates. Despite previous reports on its poor performance, it has been the recommended first-line antimicrobial of choice to young patients suspected of enteric infections attending healthcare facilities in Tanzania [17, 
27]. Meanwhile, chloramphenicol was found to have $100 \%$ effectiveness against the Gram positive bacterial isolates. Ceftriaxone and ciprofloxacin were effective antimicrobials for Gram negative bacterial isolates. Ceftriaxone is available for children under 5 years of age, but usually expensive and often administered for inpatients where as ciprofloxacin is not recommended for use in young children due to its adverse effects [27, 43]. This study found low susceptibility of S. pneumoniae isolates to amoxicillin despite this drug being commonly used for treating acute respiratory infections in Tanzanian children [27]. These data highlight the need to conduct further studies so as to facilitate policy makers to revise antimicrobial use guidelines accordingly. Periodic in vitro susceptibility testing of antimicrobials is essential to provide guidance for appropriate and effective treatment against bacterial infections as well as understanding the local antimicrobial resistance patterns. Hence, adequate microbiology laboratory facilities are essential and highly needed.

The study had some potential limitations. First, there was no confirmation evidence of prior use of antimicrobial drugs among patients instead the study relied on information provided by the parents/legal guardians. Second, the sensitivity of blood culture is known to be less than $100 \%$. Therefore the use of a single culture bottle may have contributed to the low detection of bacteria pathogens [44]. Third, difficulty in venous sampling from young patients might have added to the low yield of bacterial pathogens. Lastly, the study could not provide sufficient bacterial isolates for in-depth characterisation of antimicrobial susceptibility pattern.

\section{Conclusion}

In conclusion, bacteraemia was uncommon. This study highlights the need for rational use of antimicrobial prescription in febrile paediatric outpatients presenting at healthcare facilities in rural Tanzania. Accurate diagnosis of bacterial infections in Tanzania remains a challenge because of non-specific symptoms and the lack of reliable diagnostic tools. Clinicians are therefore advised to withhold prescription of antibiotics to non-severe cases of febrile illnesses unless proven by laboratory results.

\section{Author's contributions}

All authors conceived, designed the experiments and contributed to the writing of this manuscript. CM, AB and PL conducted the study and participated in the laboratory analysis. $C M, J L$ and $B N$ analysed the data. $C M$ wrote the paper. All authors read and approved the final manuscript.

\footnotetext{
Author details

${ }^{1}$ Korogwe Research Laboratory, Tanga Centre, National Institute for Medical Research, P. O. Box 5004, Tanga, Tanzania. ${ }^{2}$ Department of Medical Entomology and Parasitology, School of Public Health, Muhimbili University of Health and Allied Sciences, P. O. Box 65001, Dar es Salaam, Tanzania. ${ }^{3}$ Department of International Health, Microbiology and Immunology, University of Copenhagen, Copenhagen, Denmark.
}

\section{Acknowledgements}

Our sincere thanks go to all children and their parents/guardians who participated in the study. We give thanks to Korogwe District Hospital management for their support during the study. We thank all clinical and laboratory personnel working at the National Institute for Medical Research Korogwe Laboratory: Samwel Gesase, Samuel Sembuche, Monica Billa, the late Boniface Eustack; Neema Malle, Theresia Joseph, Thabita Joseph, Martin George and Joyce Mbwana. We thank Mohammed Mapondela, Neema Barua, Mary Lukindo and Filbert Francis for database management. We gratefully acknowledge PATHMVI, RTS, S and Afrique-One Projects for their support during the study. We thank NIMR Director General for permission to publish this work. The study was funded by the Swedish International Development Cooperation Agency (SIDA) through Muhimbili University of Health and Allied Sciences.

\section{Compliance with ethical guidelines}

\section{Competing interests}

The authors declare that they have no competing interests.

Received: 17 November 2014 Accepted: 19 May 2015

Published online: 03 July 2015

\section{References}

1. Reddy EA, Shaw AV, Crump JA (2010) Community-acquired bloodstream infections in Africa: a systematic review and meta-analysis. Lancet Infect Dis 10:417-432

2. Scott JA, Berkley JA, Mwangi I, Ochola L, Uyoga S, Macharia A et al (2011) Relation between falciparum malaria and bacteraemia in Kenyan children: a population-based, case-control study and a longitudinal study. Lancet 378:1316-1323

3. Crump JA, Ramadhani HO, Morrissey AB, Msuya LJ, Yang LY, Chow SC et al (2011) Invasive bacterial and fungal infections among hospitalized HIVinfected and HIV-uninfected children and infants in northern Tanzania. Trop Med Int Health 16:830-837

4. Berkley JA, Bejon P, Mwangi T, Gwer S, Maitland K, Williams TN et al (2009) HIV infection, malnutrition, and invasive bacterial infection among children with severe malaria. Clin Infect Dis 49:336-343

5. D’Acremont V, Kilowoko M, Kyungu E, Philipina S, Sangu W, Kahama-Maro J et al (2014) Beyond malaria-causes of fever in outpatient Tanzanian children. N Engl J Med 370:809-817

6. Bassat Q, Guinovart C, Sigauque B, Mandomando I, Aide P, Sacarlal J et al (2009) Severe malaria and concomitant bacteraemia in children admitted to a rural Mozambican hospital. Trop Med Int Health 14:1011-1019

7. Mtove G, Amos B, von SL, Hendriksen I, Mwambuli A, Kimera J et al (2010) Invasive salmonellosis among children admitted to a rural Tanzanian hospital and a comparison with previous studies. PLoS One 5:e9244

8. Obaro S, Greenwood B (2011) Malaria and bacteraemia in African children. Lancet 378:1281-1282

9. Takem EN, Roca A, Cunnington A: The association between malaria and non-typhoid Salmonella bacteraemia in children in sub-Saharan Africa: a literature review. Malar J 2014, 13: 400

10. Mackenzie G, Ceesay SJ, Hill PC, Walther M, Bojang KA, Satoguina J et al (2010) A decline in the incidence of invasive non-typhoidal Salmonella infection in The Gambia temporally associated with a decline in malaria infection. PLoS One 5:e10568

11. Biggs HM, Lester R, Nadjm B, Mtove G, Todd JE, Kinabo GD et al (2014) Invasive Salmonella infections in areas of high and low malaria transmission intensity in Tanzania. Clin Infect Dis 58:638-647

12. Thriemer K, Ley B, Ame SS, Deen JL, Pak GD, Chang NY et al (2012) Clinical and epidemiological features of typhoid fever in Pemba, Zanzibar: assessment of the performance of the WHO case definitions. PLoS One 7:e51823

13. Were T, Davenport GC, Hittner JB, Ouma C, Vulule JM, Ong'echa JM et al (2011) Bacteremia in Kenyan children presenting with malaria. J Clin Microbiol 49:671-676

14. Bassat Q, Machevo S, O'Callaghan-Gordo C, Sigauque B, Morais L, DiezPadrisa N et al (2011) Distinguishing malaria from severe pneumonia among hospitalized children who fulfilled integrated management of 
childhood illness criteria for both diseases: a hospital-based study in Mozambique. Am J Trop Med Hyg 85:626-634

15. Petti CA, Polage CR, Quinn TC, Ronald AR, Sande MA (2006) Laboratory medicine in Africa: a barrier to effective health care. Clin Infect Dis 42:377-382

16. Reyburn H, Mwakasungula E, Chonya S, Mtei F, Bygbjerg I, Poulsen A et al (2008) Clinical assessment and treatment in paediatric wards in the north-east of the United Republic of Tanzania. Bull World Health Organ 86:132-139

17. Nadjm B, Amos B, Mtove G, Ostermann J, Chonya S, Wangai H et al (2010) WHO guidelines for antimicrobial treatment in children admitted to hospital in an area of intense Plasmodium falciparum transmission: prospective study. BMJ 340:C1350

18. Njozi M, Amuri M, Selemani M, Masanja I, Kigahe B, Khatib R et al (1097) Predictors of antibiotics co-prescription with antimalarials for patients presenting with fever in rural Tanzania. BMC Public Health 2013:13

19. Ashley EA, Lubell Y, White NJ, Turner $P$ (2011) Antimicrobial susceptibility of bacterial isolates from community acquired infections in Sub-Saharan Africa and Asian low and middle income countries. Trop Med Int Health 16:1167-1179

20. Christopher A, Mshana SE, Kidenya BR, Hokororo A, Morona D (2013) Bacteremia and resistant gram-negative pathogens among under-fives in Tanzania. Ital J Pediatr 39:27

21. Mandomando I, Sigauque B, Morais L, Espasa M, Valles X, Sacarlal J et al (2010) Antimicrobial drug resistance trends of bacteremia isolates in a rural hospital in southern Mozambique. Am J Trop Med Hyg 83:152-157

22. Leopold SJ, Van LF, Tarekegn H, Schultsz C (2014) Antimicrobial drug resistance among clinically relevant bacterial isolates in sub-Saharan Africa: a systematic review. J Antimicrob Chemother 69:2337-2353

23. National Bureau of Statistics Ministry of Finance Tanzania (2013) 2012 Population and housing census. Ministry of Finance, Tanzania (Ref Type: Report)

24. Mmbando BP, Vestergaard LS, Kitua AY, Lemnge MM, Theander TG, Lusingu JP (2010) A progressive declining in the burden of malaria in north-eastern Tanzania. Malar J 9:216

25. World Health Organisation (WHO) (2005) Intergrated Management of Childhood IIIness. Department of Child and Adolescent Health and Development $(\mathrm{CAH})$

26. Ministry of Health and Social Welfare (2007) The United Republic of Tanzania. Standard Treatment Guidelines (STG) and The National Essential Medicines List (NEMLIT) for Mainland Tanzania. Ministry of Health and Social Welfare

27. Ministry of Health and Social Welfare (2013) The United Republic of Tanzania Standard-Treatment Guidelines and Essential Medicine List, 4th edn. Ministry of Health and Social Welfare

28. Clinical and Laboratory Standards Institute (2012) Performance Standards for Antimicrobial Susceptibility Testing; Twenty-Second Informational Supplement, M100-S22, vol 32, 3rd edn. Clinical and Laboratory Standards Institute

29. Centers for Disease Control and Prevention: National Center for Infectious Diseases, World Health Organization: Department of Communicable Disease Surveillance and Response (2003) Manual for the Laboratory Identification and Antimicrobial Susceptibility Testing of Bacterial
Pathogens of Public Health Importance in the Developing World. World Health Organization

30. Mtove G, Hendriksen IC, Amos B, Mrema H, Mandia V, Manjurano A et al (2011) Treatment guided by rapid diagnostic tests for malaria in Tanzanian children: safety and alternative bacterial diagnoses. Malar J 10:290

31. Thriemer K, Ley B, Ame S, Von SL, Pak GD, Chang NY et al (2012) The burden of invasive bacterial infections in Pemba, Zanzibar. PLoS One 7:e30350

32. Nielsen MV, Sarpong N, Krumkamp R, Dekker D, Loag W, Amemasor S et al (2012) Incidence and characteristics of bacteremia among children in rural Ghana. PLoS One 7:e44063

33. Gomez-Perez GP, van BR, Grobusch MP, Dobano C (2014) Plasmodium falciparum malaria and invasive bacterial co-infection in young African children: the dysfunctional spleen hypothesis. Malar J 13:335

34. Obaro S, Lawson L, Essen U, Ibrahim K, Brooks K, Otuneye A et al (2011) Community acquired bacteremia in young children from central Nigeria-a pilot study. BMC Infect Dis 11:137

35. Marks F, Adu-Sarkodie Y, Hunger F, Sarpong N, Ekuban S, Agyekum A et al (2010) Typhoid fever among children, Ghana. Emerg Infect Dis 16:1796-1797

36. Tabu C, Breiman RF, Ochieng B, Aura B, Cosmas L, Audi A et al (2012) Differing burden and epidemiology of non-Typhi Salmonella bacteremia in rural and urban Kenya, 2006-2009. PLoS One 7:e31237

37. Murray CJ, Rosenfeld LC, Lim SS, Andrews KG, Foreman KJ, Haring D et al (2012) Global malaria mortality between 1980 and 2010: a systematic analysis. Lancet 379:413-431

38. Dewan AM, Corner R, Hashizume M, Ongee ET (2013) Typhoid Fever and its association with environmental factors in the Dhaka Metropolitan Area of Bangladesh: a spatial and time-series approach. PLoS Negl Trop Dis 7:e1998

39. Gordon MA, Graham SM, Walsh AL, Wilson L, Phiri A, Molyneux E et al (2008) Epidemics of invasive Salmonella enterica serovar enteritidis and S. enterica Serovar typhimurium infection associated with multidrug resistance among adults and children in Malawi. Clin Infect Dis 46:963-969

40. Michaela Siatta Kargbo LDMSKSXMFZ (Eds):The Relative Prevalence of Typhoid and Malaria in Febrile Patients in Freetown, Sierra Leone. In Open Journal of Preventive Medicine 2014, Vol.4No.5

41. Maurice J (2012) A first step in bringing typhoid fever out of the closet. Lancet 379:699-700

42. Cook J, Jeuland M, Whittington D, Poulos C, Clemens J, Sur D et al (2008) The cost-effectiveness of typhoid $\mathrm{Vi}$ vaccination programs: calculations for four urban sites in four Asian countries. Vaccine 26:6305-6316

43. Choi SH, Kim EY, Kim YJ (2013) Systemic use of fluoroquinolone in children. Korean J Pediatr 56:196-201

44. Lee A, Mirrett S, Reller LB, Weinstein MP (2007) Detection of bloodstream infections in adults: how many blood cultures are needed? J Clin Microbiol 45:3546-3548

\section{Submit your next manuscript to BioMed Central and take full advantage of:}

- Convenient online submission

- Thorough peer review

- No space constraints or color figure charges

- Immediate publication on acceptance

- Inclusion in PubMed, CAS, Scopus and Google Scholar

- Research which is freely available for redistribution

Submit your manuscript at 